\title{
ECONOMIE - ECONOMICS
}

\section{Pig production in the E.E.C.: Trends over the last two decades}

\author{
B. DE LA FARGE
}

Institut Technique du Porc, Pôle Economie, 34, boulevard de la Gare, 31500 Toulouse

Pig production has developed in the E.E.C. both because of new membership and of the increase in the herd size. This has led to variable results : pig price is the lowest of agricultural products. Since 1973, pig production has been increasing by 5 p. 100 per year and consumption by 4 p. 100 . The production to consumption ratio shows a 2.5 p. 100 excess. The balance of foreign trade is positive. The number of herds decreases but their size increases. stock.

Production is localized in 13 developing regions which group 75 p. 100 of the European pig

\section{Animal feed industry: Supply conditions, comparison between Brittany and the Netherlands}

\section{J. DAVID ${ }^{(1)}$, H. MAROUBY ${ }^{(2)}$, J. SAULNIER ${ }^{(3)}$}

(1) Chambre Régionale d'Agriculture de Bretagne, 111, bd de Lattre-de-Tassigny, 35000 Rennes

(2) Institut Technique du Porc, 34, bd de la Gare, 31500 Toulouse

(3) Institut Technique du Porc, La Motte-au-Vicomte, B.P. 3, 35650 Le Rheu

Feed supply of European pig production is highly dependent on imports from third countries. Thanks to the harbour of Rotterdam the Netherlands have the leadership in this field in terms both of volume and variety of imported raw materials and of harbour efficiency.

There has been a substantial increase in the unloading of feedstuffs in Western France harbours (Brittany, Pays de Loire) over the 1986-1987 period as regards grain substitutes ( 80 p. 100 of French imports). Analysis of this flow of raw materials reveals very distinct trends and situations according to harbours. Nevertheless, the harbour costs represent a handicap for purchasers (cassava, in particular) as compared to Rotterdam.

\section{Comparative technico-economic results of the E.E.C. pig herds}

\author{
G. DAUMAS ${ }^{(1)}$, O. TEFFENE ${ }^{(2)}$
}

Institut Technique du Porc

(1) Région Sud, 34, boulevard de la Gare, 31500 Toulouse

(2) Région Ouest, La Motte-au-Vicomte, B.P. 3, 35650 Le Rheu

This study supplies elements for comparing technical and economic results of pig herds from six countries of the E.E.C. : France, Germany, the Netherlands, Denmark, Belgium and GreatBritain. Data issued from management and accountancy files concern the 1980-1981 to 1985-1986 
period. The more complex criterium concern the margin on feeding costs as regards rearing of piglets and the margin on feeding costs and piglet as regards fattening. stage.

The present trend has increased the delay of France relative to its partners at the rearing

Moreover, Germany and to a less extent the Netherlands and Belgium benefit from a more favourable VAT system.

\title{
Economic risk and technical change in pig production
}

\section{F. COLSON}

Institut National de la Recherche Agronomique

Laboratoire d'Etudes Economiques sur les Industries Agricoles

et Alimentaires, Chemin de la Géraudière, 44072 Nantes Cedex

Pig production is characterized by the large variability of economic results due to fluctuation of market prices and to differences in technical efficiency among pig breeders.

Pig farming units are more indebted than the other animal raising systems, but the income is equal or superior to that of the others.

The development of pig production highly depends on the search for new methods or herd management which contributes to reducing the economic risks for pig production investors.

\section{Market prices of slaughter pigs in the E.E.C. : Adjustment before comparison}

\author{
G. DAUMAS \\ Institut Technique du Porc, 34, bd de la Gare, 31500 Toulouse
}

National quotations of slaughter pigs constitute a privileged means of comparison between E.E.C. countries, but their mode of calculation remains highly different. The purpose of the present study was to determine the distorsion factors and to quantify them in four countries : France, Germany, the Netherlands and Denmark in September 1987.

Some factors depend on type qualities defined on the basis of carcass grading scales, and particularly on problems of lean content measurement. The others concern the carcass presentation and the hot-cold rebate, the commercialization stage and the weighting of regional quotations.

Using these elements, it is possible to correct reference quotations to improve their comparison ability. 